\title{
Analytisk musiklytning og udvikling af universitetsstuderendes kompetencer inden for kvalitativ forskning
}

Julie Borup Jensen, konstitueret lektor, Institut for Laring og Filosofi, Aalborg Universitet.

\section{Faglig artikel (bedømt af redaktionen)}

Artiklen formidler et undervisningseksperiment om analytisk musiklytning, hvis hensigt var at styrke kandidatstuderendes kompetencer indenfor kvalitative forskningsog dataindsamlingsmetoder. Data om eksperimentet stammer fra egen undervisningsportfolio og et kvalitativt spørgeskema til de deltagende studerende, og de analyseres $i$ et sociokulturelt og aestetisk laeringsperspektiv. Eksperimentet byggede på en antagelse om, at kvalitative forskningsmetoder udnytter en grundlaeggende menneskelig erkendelsesform, der går gennem sanserne: når man interviewer, lytter man og bruger hørelsen som udgangspunkt for at forstå det andet menneske, når man observerer, ser man og bruger synet for at forstå omgivelserne. Dette aspekt af den kvalitative forskningstilgang opleves af de studerende som vanskelig og udfordrende. Derfor gik eksperimentet ud på at rette de studerendes opmaerksomhed mod forskellen mellem at lytte/se på den ene side og fortolke det hørte/sete på den anden. Resultaterne peger på, at musiklytning ud fra musikanalytiske principper støttede de studerende i denne skelnen, og at musik, qua sin lidt 'fremmede' tilstedevorelse i undervisningsrummet muliggjorde refleksioner over det at finde mening i ukendte empiriske kontekster.

\section{Introduktion}

Kan musiklytning anvendes didaktisk i undervisningen af universitetsstuderende, der forventes at tilegne sig kompetencer inden for kvalitativ forskning? Dette spørgsmål var grundlaget for et undervisningseksperiment gennemført i forbindelse med mit adjunktpædagogikumforløb. At lære kvalitative forskningsmetoder sammenlignes ofte med at lære et håndværk: det kræver træning, gentagelse og opbygning af erfaring (Brinkmann, 2012; Hammersley, 2004). Dette afspejles implicit af teoretiske metaforer for etnografiske dialog- og observationsmetoder, såsom at forskeren kan positionere sig som 'den fremmede', 'den rejsende' mv. (Wadel, 1991), eller at indsamling af data handler om at 'sætte sin forforståelse i parentes', når man med et fænomenologisk udgangspunkt observerer og skriver feltnoter eller 'lytter åbent' i interviewet (Krogstrup \& Christiansen, 1999; Brinkmann, 2012). Det er imidlertid påfaldende, at metodelitteraturen sjældent forklarer, hvordan man egentlig lærer at 'sætte sin forforståelse i parentes' eller at positionere sig som 'den fremmede'. 
Denne problemstilling overlades hermed bl.a. til underviserne selv eller til universitetspædagogiske forskere (Breuer \& Schreier, 2007) der da også leverer nogle bud: for eksempel at lade de studerende deltage i deres egen, kvalitative dataindsamling $\mathrm{i}$ en slags 'mester-lærlinge'-relation (Hammersley, 2004; Whiting, 2008), laboratorieøvelser, hvor studerende interviewer eller observerer hinanden (Babbie, 2003; Tanggaard, 2006; Elmholt, 2006), eller et decideret 'interviewpraktikum' (Tanggaard, 2006).

Imidlertid kan det problematiseres, at metodelitteraturen og universitetspædagogikken sjældent forholder sig til, at udvikling af forskningskompetencer ikke kun drejer sig om tilegnelse af metodiske greb. I kvalitativ forskning indgår også en personlig udviklingsdimension, hvor forskerens måde at se og høre på spiller ind i processen (Hastrup, 2010). Det betyder, at der i undervisningen i kvalitative metoder med fordel kunne indgå didaktiske elementer, hvor den studerende forberedes på den konkrete dataindsamling: eksempelvis, hvordan lytter man åbent i interviewsamtalen, eller hvordan forholder man sig åbent til feltet? Det er her, analytisk musiklytning kan have et potentiale, som jeg vil beskrive gennem et undervisningseksperiment, gennemført under mit adjunktpædagogikumforløb ved Aalborg Universitet.

\section{Baggrund for eksperimentet}

Begrundelsen for at anvende analytisk musiklytning var, at kvalitative dataindsamlingsmetoder som interview, observation og feltarbejde grundlæggende udnytter menneskets kropsligt-sanselige udgangspunkt for erkendelse i dataindsamlingsøjemed. Når der derfor i metodelitteraturen tales om at 'sætte sin forforståelse i parentes', eller at 'lytte åbent', så betyder det, at forskeren lærer at koncentrere sig om det, vedkommende ser og hører i felten, i første omgang oven i købet så vidt muligt uden at fortolke og meningstilskrive (Hastrup, 2010; Raudaskosi, 2010). Det betyder forenklet sagt, at de studerende skal lære at adskille det, der med et fænomenologisk udgangspunkt kan kaldes sansning og fortolkning (Løgstrup, 1993). Denne adskillelse af det sansede (se og høre) og fortolkningen (hvordan forstås det, der ses og høres) kan opleves som yderst vanskelig, fordi den går imod vores umiddelbare måde at erkende på, hvor det sansede og fortolkningen sker næsten simultant, således at vi kan handle uden at blive besværet af for mange overvejelser over sanseindtryk i dagligdagen (Løgstrup, 1993; Polanyi, 1958; Dreyfus \& Dreyfus, 1991). Derfor var eksperimentet udformet med henblik på at træne adskillelsen af sansning og fortolkning gennem musiklytning ud fra musikanalytiske metoder (Englund, 2008; Brincker, 1990). Den klassiske musikanalyses adskillelse af sansede og fortolkede dimensioner af den musikalske oplevelse har til formål at skabe en konsistent fortolkning af et stykke musik: 1) Først beskrives musikken så nøjagtigt som muligt, som den fremtræder 'fysisk' (det sansede). 2) På grundlag af trin 1 foretages trin 2), som er en indre fortolkning (den mening lytteren tilskriver musikken). Trin 3) er en ydre fortolkning (lytterens forestilling om komponistens hensigt og bidrag til musikkens felt) 
(Englund, 2008; Brincker, 1990). Det vil sige, at den samlede fortolkning underbygges af konkrete observationer fra analysens trin 1.

Dette mente jeg havde nærmest direkte overførelsesværdi til undervisningen i kvalitativ dataindsamling: formålet med feltobservationer er forenklet sagt at gennemføre så forudsætningsløs en beskrivelse af feltet som muligt for, med grundlag i konkrete observationer, at kunne underbygge de fortolkninger og meningstilskrivninger, som forskeren arbejder videre med i det empiriske forskningsarbejde (Hastrup, 2010; Raudaskosi, 2010). Antagelsen bag eksperimentet var således, at analytisk musiklytning kunne gøre de studerende opmærksomme på en grundlæggende form for sansebaseret, beskrivende erkendelse, de ville få brug for i deres feltarbejde, og undersøge, om den havde overførelsesværdi i forhold til det, de får brug for i observationsstudier og udførelsen af interviews. Jeg omarbejdede derfor ovenstående analysetrin (Brincker, 1990) til et analyseskema med et mindre fagspecifikt sprog (se tabel 2), der skulle understøtte, at de studerende fik mulighed for at erfare forskellen mellem det, de hørte, og det, de oplevede og fortolkede i musikken, som udgangspunkt for at reflektere over sansningens og forståelsens betydning i feltarbejde.

Eksperimentets undersøgelsesspørgsmål var derfor: kan analytisk musiklytning understøtte udvikling af studerendes observationsevne i feltstudier?

\section{Kontekst: et tværfagligt hold af kandidatstuderende}

For at forstå konteksten for undervisningseksperimentet beskrives i det følgende relevante undervisningsmæssige rammer. Eksperimentet foregik på 9. semester på en humanistisk kandidatuddannelse på Aalborg Universitet. Studiet retter sig mod jobfunktioner som eksempelvis uddannelsesudviklere, innovationsmedarbejdere samt HR-funktioner og andre tværgående funktioner inden for læring og forandring i offentlige og private organisationer. Uddannelsens indhold er en tværfaglig kombination af læringsteori, pædagogik, didaktik og kulturteori, og de studerende forventes, ud over at tilegne sig den problem- og projektorienterede forskningsmetode, at oparbejde kompetencer inden for kvalitative, antropologiske og etnografiske forskningsmetoder i feltet læring og forandring. Optaget af studerende er bredt: universitetsbachelorer fra fagområder som Sociologi, Kommunikation, Psykologi og Idræt optages på uddannelsen sammen med professionsbachelorer fra især lærer- og pædagoguddannelserne samt fra Ernæring og Sundhed.

Samlet set er der derfor tale om sammensatte hold og en uddannelse, der kræver udvikling af stærke kommunikative, pædagogiske, analytiske og problemløsende kompetencer. Dette er således også et af formålene med, at de studerende på 9. semester indgår i et praksisforløb med en institution eller virksomhed, hvor læringsmålet er at opøve feltarbejdsmetoder i relation til lærings- og forandringsforløb, som de gennemfører med en selvvalgt målgruppe. 9. semester var derfor nøje ud- 
valgt som målgruppe for mit undervisningseksperiment, fordi de studerende netop på dette semester ofte udfordres af problemstillinger omkring valide feltbeskrivelser.

\section{Adjunktportfolier, kompetenceudvikling og forskningsmetodologi (H1)}

Inden jeg fremlægger eksperimentet, vil jeg gøre rede for mine datakilder og øvrige metodiske overvejelser i forbindelse med formidling af forskning i egen praksis. De empiriske beskrivelser stammer fra to kilder:

1. Min undervisningsportfolio, produceret som led i deltagelse i Adjunktpædagogikum ved Aalborg Universitet, og

2. En kvalitativ, skriftlig interviewundersøgelse af de kandidatstuderende, der deltog i undervisningseksperimentet

Undervisningsportfolien var udformet både som en dag-/logbog og som et refleksionsredskab. Metodologisk set stammer idéen om logbogsføring som et redskab til faglig udvikling fra forskning i professionsudvikling. Logbogen er et redskab, hvormed den professionelle underviser individuelt kan beskrive og følge egen udvikling og læring, men den kan også være et redskab til offentlig dokumentation af udførte aktiviteter og udviklede metoder (Dysthe \& Engelsen, 2011; Havnes \& Lauvås, 2004). Logbogen i sig selv er dog ikke tilstrækkelig som grundlag for forskning eller formidling; den skal bearbejdes som alle andre former for data i lyset af relevante problemstillinger og begreber i det givne praktiske og videnskabelige felt. Derfor udviklede jeg en metode til systematisk udvikling af logbogens datamateriale inspireret af Donald Schön (1987). Schöns tre kategorier, 'viden-i-handling', 'refleksion-i-handling' og 'retrospektiv refleksion' (ibid., s. 22-31), har dannet grundlag for en tre-kolonnet, analytisk ramme for databearbejdning:

\begin{tabular}{|l|l|l|}
\hline $\begin{array}{l}\text { Beskrivelse } \\
\text { (viden-i-handling) }\end{array}$ & $\begin{array}{l}\text { Refleksion } \\
\text { (refleksion-i-handling) }\end{array}$ & $\begin{array}{l}\text { Teoretiske begreber } \\
\text { (refleksion over handlingen) }\end{array}$ \\
\hline & & \\
\hline
\end{tabular}

Tabel 1: Matrix for dataanalyse (baseret på Schön, 1987).

Kolonnen til venstre er beregnet til "rå data", dvs. de uredigerede lognotater fra min undervisning. Kolonnen i midten er til fortolkning og meningskondensering af data (logbogstekster). Kolonnen til højre bearbejder de to første kolonner ved at inddrage teoretiske perspektiver og begreber ved hjælp af hvilke, data og fortolkning kan forstås og "oversættes" til generelle teoretiske begreber. Således gør analyserammen det muligt at bringe observationer og beskrivelser fra min egen praksis i spil med en bredere teoretisk begrebsramme, sådan som også Giorgi anbefaler i sin fænomeno- 
logiske analysemetodik (Giorgi, 1975). I dette tilfælde er den begrebslige hovedramme for analyse et sociokulturelt, æstetisk læringsperspektiv, som forventes at indfange den analytiske musiklytnings virkning på de studerendes læring. Dette har muliggjort, at det partikulære eksperiment kan bidrage til en mere generel viden om analytisk musiklytnings virkninger på studerendes læring (Giorgi, 1975).

Analyserammen samler således et fænomenologisk (kolonne 1) og hermeneutisk (kolonne 2 og 3) perspektiv på vidensskabelse i et praksisorienteret redskab. Formålet er kvalitativ udvikling af viden baseret på et samspil mellem underviserens livsverdenserfaringer og beskrivelser af fænomener (kolonne 1) og deraf opståede fortolkninger som følge af erfaringsbaseret refleksion (kolonne 2) og teoretiske forståelser (kolonne 3) (Giorgi, 1975).

Brugen af egne beskrivelser, pædagogiske overvejelser og handlinger som datamateriale gør til en vis grad den metodiske tilgang autoetnografisk (Collins, 2010). Styrken ved denne type data er, at forskerens egen stemme tydeligt fremgår (Denshire, 2014). Imidlertid kan det introspektive perspektiv modarbejde troværdigheden af data. For at tage højde for dette problem har jeg, fremfor at fremhæve de emotionelle eller litterære aspekter af undervisningseksperimentet (Collins, 2010), tilstræbt at beskrive eksperimentet så visuelt som muligt, og at holde mine tanker ude af beskrivelsen. For at kvalificere egne optegnelser yderligere, udarbejdede jeg et kvalitativt evaluerings- og interviewskema til de studerende. Indholdet af interviewskemaet er beskrevet nedenfor i forbindelse med selve fremstillingen af eksperimentet.

I forbindelse med denne artikel er mine forsknings- og formidlingsetiske overvejelser rettet mod de studerende, som er beskrevet samt citeret. På trods af at forskning inden for humaniora ikke indebærer en risiko for fysisk skade, bør den alligevel indeholde overvejelser over at minimere risikoen for andre typer af ulemper for informanterne (Statens Samfundsvidenskabelige forskningsråd, 2002; Brinkmann, 2012). I mit tilfælde, hvor jeg beder de studerende besvare et spørgeskema, der er designet af mig som deres underviser, kan der opstå integritetsmæssige risici for de studerende, da de kan føle sig presset til at besvare det eller presset til at forholde sig emotionelt til en undervisning, de måske helst vil glemme alt om. Rent bortset fra etiske problematikker kan der også opstå en validitetsmæssig risiko for ubalancerede svar i spørgeskemaet, for eksempel at de studerende forsøger at gætte hvilke svar, jeg ønsker fra dem qua min magtposition i forhold til kommende eksamener mv.

Jeg har behandlet disse risici ved at sikre anonymitet og frivillighed. Spørgeskemaet var webbaseret (SurveyXact) og fremstillet uden muligheder for at opspore de studerendes identitet. Webbaseringen gjorde desuden besvarelsen af spørgeskemaerne frivillig, fordi de studerende aktivt skulle åbne og gennemføre det. For at opfylde principper om integritet (Ibid.) er alle beskrivelser anonymiseret, så præcise steder 
eller personer er uidentificerbare i det omfang, det er muligt, da jeg som forfatter af artiklen ikke er anonym.

\section{Analytisk musiklytning som forberedelse til feltobservation og interview}

Eksperimentet drejede sig som nævnt om analytisk musiklytning som forberedelse til udvikling af observations- og interviewkompetencer. Det faglige tema for undervisningen var "hvordan observeres læring i praksis?" Sessionen startede ud med en powerpoint-understøttet forelæsning, hvor forskellige etnografiske tilgange til observationsstudier i egen praksis blev skitseret, bl.a. begreberne 'sætte forforståelsen i parentes' og Wadels deltagerpositioner (Wadel, 1991).

Dette blev efterfulgt af den analytiske musik-observationsøvelse. Morgenstemning af Edvard Grieg (1876) blev afspillet. De studerende fik opgaver til tre dimensioner i lytningen: en sansende dimension, samt en indre og ydre fortolkende dimension. Opgaven inden for den sanselige dimension var at identificere det rent lydlige i musikken, såsom hvilke instrumenter, der spillede, tempo (hurtigt eller langsomt), hvor kraftigt eller svagt instrumenterne spillede, og hvor mange instrumenter, der spillede på én gang. I den indre-fortolkende dimension var opgaven at uddybe oplevelsen af musikken, eksempelvis om de så billeder, farver, handlingsforløb, enkelthandlinger for sig, eller om de forbandt musikken med en speciel stemning eller følelse. Og endelig, inden for den ydre fortolkende dimension, var opgaven at forestille sig, hvilken intention komponisten havde med musikken. Nedenstående skema blev udleveret som støtte til deres lytning:

\begin{tabular}{|l|l|l|}
\hline $\begin{array}{l}\text { Hvad hører jeg (hvilke in- } \\
\text { strumenter, kraftig/svag, } \\
\text { hurtig/langsom, mange/få } \\
\text { instrumenter etc.)? }\end{array}$ & $\begin{array}{l}\text { Hvad gør musikken (ser jeg } \\
\text { billeder for mig, farver, en } \\
\text { handling, en atmosfære } \\
\text { eller stemning, er der følel- } \\
\text { ser? Hvilke?) }\end{array}$ & $\begin{array}{l}\text { Hvad handler musikken } \\
\text { om? Hvad vil komponisten } \\
\text { fortælle? }\end{array}$ \\
\hline & & \\
& & \\
\hline
\end{tabular}

Tabel 2: Analytisk musiklytning.

Undervisningen afsluttedes med en mundtlig opfølgning med refleksionsspørgsmål, der relaterede øvelsens adskillelse af sansning og fortolkning til interview- og observationsmetode. Her var spørgsmålet, om musikanalysen havde givet nye indsigter $\mathrm{i}$ feltstudierne, og om analysen fik betydning for opfattelsen af forskerrollen og opgaven.

De studerendes udsagn skrev jeg straks efter lektionen ned i min undervisningslog. Udsagnene blev anvendt til udarbejdelse af spørgsmål i et kvalitativt interviewskema til det samme hold studerende, hvor de et år efter færdiggjort uddannelse blev bedt 
om at huske og forholde sig til øvelsen. Interviewskemaet var udformet med åbne spørgsmål og med tekstfelter til besvarelse. De åbne spørgsmål og svarfelter betød, at de studerendes kvalitative beskrivelser af, hvordan de huskede og oplevede musikanalysen fra et livsverdensperspektiv, var i overensstemmelse med den fænomenologiske-hermeneutiske tilgang til empirisk, kvalitativ undersøgelse (Brinkmann, 2012).

Spørgeskemaet blev oprettet i programmet SurveyXact og udsendt til de studerende gennem holdets lukkede Facebook-gruppe. 12 ud af 36 studerende responderede, og eftersom spørgeskemaet var designet til at indhente de studerendes refleksioner over øvelsen og ikke til at udføre en statistisk beregning, anses dette for en tilfredsstillende svarprocent.

\section{Musik som metafor for "det uforståelige" $i$ en fremmed kontekst}

De studerende i mit eksperiment oplevede som forventet vanskeligheder med at beskrive musikken som lyd. Dette skyldtes ikke alene, at musik ofte har direkte følelses- og erfaringsmæssige responser, hvilket vanskeliggør en adskillelse af det, man hører, fra det, man føler og tænker (Bonde, 2009), men også, at de studerende oplevede, at de grundlæggende manglede sprog til at beskrive musik. Følgende udsagn beskriver, hvad der gik igen igennem besvarelserne:

"Det var som om musikken var et helt fremmed sprog - Jeg ved, at musik har sin egen terminologi, men jeg kender den ikke, så det var meget svart at beskrive, hvad jeg hørte i musikken."

En anden studerende skrev i spørgeskemaet:

"Når man ikke engang kan identificere instrumenterne eller skelne dem fra hinanden, er det umuligt at beskrive det musikalske indtryk."

Af min logbog fremgår det, at disse indvendinger også kom til udtryk i selve undervisningen. På det metaforiske plan kunne de studerende dog overføre denne emotionelle oplevelse af frustration over et utilstrækkeligt musikalsk ordforråd til det at udføre kvalitative observations- og interviewundersøgelser i en ukendt kontekst: de sammenlignede egen oplevelse af musikken som "et fremmed sprog" med oplevelsen af at observere og interviewe i en organisation, hvor dens indforståetheder og kulturelle markører også kan opleves som et "fremmed sprog". På den måde gav musiklytningen anledning til en metarefleksion over den forskningsmæssige opgave og udfordring, der handler om overhovedet at skabe tilstrækkelig meget mening i det, man ser og hører i observationer og interviews, til, at man kan beskrive det.

En lignende refleksion gik igen i en af de studerendes besvarelser i spørgeskemaet et år efter: 
"Efter vores drøftelser om musikøvelsen i plenum, hvor jeg til at begynde med ikke kunne tale med om de musiske fagtermer, reflekterede jeg over den måde, jeg selv talte på, da jeg var i min praksiskontekst - det fik mig til at reflektere over, hvorvidt jeg brugte [mit eget] fagsprog, som for andre kan vore uforståeligt."

Det vil sige, at denne studerende reflekterede over sin egen måde at indgå som forsker i en praksiskontekst. Oplevelsen af det ekskluderende i ikke at mestre "de musiske fagtermer" blev overført til en refleksion over egen brug af fagtermer i den konkrete forskningspraksis: om vedkommende mon selv brugte et sprog, der var ekskluderende i forskningskonteksten.

\section{'At sætte forforståelsen i parentes' - giver det mening?}

Det, at de studerende hørte hinandens beskrivelser og fortolkninger af det samme stykke musik, gav anledning til følgende udsagn:

"[...] Jeg fik prøvet på egen krop, hvor forskelligt mennesker opfatter virkeligheden jeg blev virkelig klar over vigtigheden af at vaere bevidst om mine egne forforståelser og den måde jeg opfatter virkeligheden på, og at vaere åben og forsøge at forstå informanten for at få alle nuancerne af undersøgelsesområdet afdcekket."

Udsagnet peger på en erkendelse af, at når egen og andres oplevelse af et stykke musik kan være forskellige, kan oplevelser af mere dagligdags hændelser, som er genstandsfeltet i kvalitative studier, også være det. En fortolkning er, at denne studerende ved at høre holdets forskelligheder i beskrivelse og fortolkning af musikken oplevede grunden til, at metodelitteraturen lægger vægt på 'at sætte forforståelsen i parentes' og 'forholde sig åbent' i observationer og interviews. Også det næste citat underbygger en sådan virkning:

"Efter øvelsen indså jeg, at hvad vi havde gjort, var, at vi så, hørte, fornemmede og oplevet dybt, hvad der menes med empirisk stringens. I feltobservationer, er det ikke nok, at du hører, hvad du forventer at høre eller 'tror, at du hører', fordi tonen i stemmen og kropssprog kan fortoelle dig endnu mere. Du er nødt til virkelig at lytte."

Dette og de øvrige citater fra den kvalitative spørgeskemaundersøgelse peger henimod, at musiklytningen muliggjorde en konkret erfaring om vigtigheden af i feltforskningsarbejde at adskille sansebaseret beskrivelse af de empiriske sammenhænge på den ene side, og fortolkning på den anden.

\section{Analytisk musiklytning som læringsredskab}

Med de empiriske eksempler ovenfor har jeg skitseret en række oplevede virkninger af analytisk musiklytning hos 9. semestersstuderende på en bestemt kandidatuddannelse. For at kunne sige noget mere generelt og med overførelsesværdi til andre 
kontekster vil jeg i det følgende sætte eksemplerne i spil med læringsteoretiske begreber for slutteligt at forstå dem i et universitetspædagogisk perspektiv.

\section{Musik og læring}

Hvis man stiller spørgsmålet, hvad de studerende har lært af musikanalyseøvelsen, vil svaret afhænge af, hvordan læring forstås. Musikanalysen var designet til at understøtte en bevidstgørelse af samspillet mellem sanser og fortolkning og dettes betydning for forskningsarbejde i hhv. dialog/interviews og iagttagelse/observation. Det empiriske materiale peger på, at dette lykkedes hos i hvert fald et antal af de studerende. Før der kan uddrages mere generelle indsigter med relevans for andre undervisningskontekster, vil det imidlertid være nødvendigt at undersøge, hvordan den kropslige dimension af læring kan forstås begrebsligt, og hvilke typer af kompetencer, denne læring forventes og ønskes at føre til (Giorgi, 1975; Brinkmann, 2012).

I pragmatiske og sociokulturelle teorier om læring ses individets skabelse af mening som afgørende tegn på læring (fx Dewey, 1980; Vygotsky, 1930/2000; Lave \& Wenger, 2003; Bruner, 1997; Schön, 2001). Denne meningsskabelse afhænger af, hvordan materialitet og fysiske, sociale og kulturelle omgivelser fungerer som fælleskulturelle, meningstilskrivende elementer i læreprocessen (Bruner, 1997, s. 75), og dermed ekspliciteres omgivelsernes betydning for læring. Krop og sanser synes at have underforstået betydning for læring, fordi konstruktion af mening, viden og forståelse altid sker i relation til noget, men kroppens betydning er sjældent ekspliciteret. I modsætning hertil betoner æstetiske læringsteorier, at den lærende i lige så høj grad gøres opmærksom på dette noget, altså det sete og hørte, som på den sociale, emotionelle og begrebslige betydning, der tillægges sanseindtrykket - man dvæler ved sanseindtrykket for at skabe læring (Eisner, 2008; Langer, 1969).

I dette lys peger de studerendes udsagn på, at musikanalysen retter opmærksomheden mod det noget (musikkens fysiske fremtræden som lyd og deres måde at høre på), som tilskrives mening. Dermed giver musikanalysen de studerende mulighed for at erfare forskellen mellem det, de sanser, og det, de tillægger af mening. Dette danner udgangspunkt for at undersøge deres måder at tilskrive mening til det, de hører og ser i dataindsamlingsprocesser (jf. citat ovenfor: "[...] er det ikke nok, at du hører, hvad du forventer at høre[...]").

En yderligere, sociokulturel dimension føjes til i kraft af, at de studerende foretager analysen i fællesskab. Her får de ifølge citaterne mulighed for at erfare, at både beskrivelser og meningstilskrivninger forekommer forskellige, men dog genkendelige, fra person til person. Det danner udgangspunkt for en refleksion over, at deltagerne i det forskningsfelt, de studerende skal ud i qua deres studiemål, kan have en anden, men dog genkendelig, tilskrivning af mening til de observerede handlinger, end den studerende, som forsker (jf citat ovenfor: "[... ]bevidst om mine egne forforståelser og den måde jeg opfatter virkeligheden på, og at vore åben og forsøge at forstå informanten 
for at få alle nuancerne af undersøgelsesområdet afdoekket."). I lyset af sociokulturelle læringsteorier bliver den kulturelle dimension af meningstilskrivning således tydeliggjort gennem den analytiske musiklytning. På den måde muliggøres en ny erfaringsbaseret forståelse af det at 'forholde sig åbent' til forskningsfeltet eller 'sætte sin forforståelse i parentes'. Dermed kobles sammenhængen mellem det sansede og selve betydningsdannelsen direkte til den sanselige og betydningsdannende dimension af det at forske kvalitativt.

\section{Perspektiver for universitetspædagogik}

Hvis det beskrevne eksperiment ses i lyset af et fremtrædende universitetspædagogisk begreb som 'constructive alignment', opstår der imidlertid en række dilemmaer. Et karakteristisk træk ved alignment-tilgangen er, at der skal være en direkte reference fra det, der undervises i, til det, der eksamineres i ved forløbet afslutning (Biggs, 1990). Hvis alignment forstås alene i forhold til den studieordningsmæssige og formelle ramme for de studerendes læring kan eksperimentet ses som en ekskurs i forhold til det, den studerende prøves i efter semesterets slutning, idet der ikke kan identificeres en klar linje fra eksperimentets indhold (bevidstgørelse af sansernes betydning for forskningsarbejde) til formuleringerne i studieordningsmålet, således som Biggs (1996) anbefaler. Kompetencemålet inden for kvalitativ forskning er i studieordningen for 9. semester formuleret således:

"at kunne igangsaette og styre et komplekst undersøgelsesarbejde baseret på videnskabelige kriterier, analysemodeller og metoder inden for laerings- og uddannelsesområdet i en specifik praksiskontekst" (Studieordning, AAU, 2012).

Kropsligt-sanselige aspekter af læreprocesser og forskningsprocesser indgår ikke i formuleringen af dette mål, og dermed kan eksperimentet ikke ses som en del af alignment i forhold til studieordningen.

På den anden side kan der identificeres en klar sammenhæng mellem den litteratur, de studerende forventes at anvende som grundlag for at udvikle kompetencer i kvalitativ dataindsamling ( $f x$ Brinkmann, Wadel, Hastrup m.fl.), og eksperimentets fokus på dimensioner af læring, som indgår i udviklingen af et håndværk. Her vil det være oplagt at drøfte, i hvilket omfang, og på hvilket niveau, "klare, velbeskrevne mål og bevidsthed om arbejdsformer og prøveformer kan motivere de studerende til at påtage sig selv at loere det, som intenderes" (Leth Andersen, 2010, s. 31). Eksperimentet kunne nuancere de overvejende kognitivt baserede måder at tænke uddannelse på, som er fulgt i kølvandet på constructive alignment-tænkningen, som også Andersen er inde på i en kritisk analyse (Andersen, 2010), ligesom det kan overvejes, om det er tilstrækkeligt at formulere akademiske kompetencer i kognitive termer. På den baggrund kan det være nødvendigt at overveje didaktikker, der bygger videre på det at læse, høre forelæsning og diskutere, altså kognitive og verbalsproglige læringsmå- 
der. Ikke fordi det er uproblematisk at udvide alignment-tænkningen med andre typer af læringsforståelser, som også udsagnene fra de studerende peger på, men fordi det ud fra visse typer af kompetenceudvikling, som eksempelvis kvalitative forskningskompetencer, kunne være nødvendigt at gøre det.

Julie Borup Jensen er lektor i kreativitet og kunstbaserede loereprocesser ved Aalborg Universitet, Institut for Loering og Filosofi. Hun har i de seneste år forsket i loerings-, kreativitets- og innovationspotentialer til at understøtte aestetiske loeringsformers samspil med andre loeringsformer i videregående uddannelse på professionshøjskoler og på universitetet. Dette fokus har ført til en raekke udviklingsarbejder i uddannelsesprogrammerne på Institut for Loering og Filosofi på master- og kandidatniveau, hvor studenterdiversitet har voeret omdrejningspunktet. Her er det iscer kunstens potentialer for at involvere krop, sanser og emotioner i samspil med refleksive og kognitive laereprocesser i praktiske og akademiske kontekster, der er fokus for interessen. Denne interesse involverer desuden et fokus på uddannelsesforskningens muligheder for at indfange og omsatte viden om kroppens betydning i uddannelsessystemet.

\section{Litteratur}

Andersen, H. L. (2010). »Constructive alignment« og risikoen for en forsimplende universitetspædagogik. Dansk Universitetspœedagogisk Tidsskrift, 5(9), 30-35.

Babbie, E. (2003). Lessons learned from teaching qualitative methods. Qualitative Research Journal, 11(23).

Biggs, J. (1996). Enhancing teaching through constructive alignment. Higher Education; the International Journal of Higher Education and Educational Planning, 32(3), 347364. doi:10.1007/BF00138871.

Bonde, L. O. (2009). Musik og menneske: Introduktion til musikpsykologi. Frederiksberg: Samfundslitteratur.

Breuer, F. \& Schreier, M. (2007). Issues in learning about and teaching qualitative research methods and methodology in the social sciences. Forum Qualitative Sozialforschung /Forum: Qualitative Social Research, 8(1) http://www.qualitativeresearch.net/index.php/fqs/article/view/216/477.

Brincker, J. (1990). Musiklore og musikalsk analyse (2. rev. og udvidede udg.). København: Engstrøm \& Sødring.

Brinkmann, S. (2012). Qualitative Inquiry in Everyday Life. London: Sage publications Itd.

Bruner, J. (1997). The Culture of Education. Cambridge: Harvard University Press.

Collins, P. (2010). The ethnographic self as resource? I P. Collins \& A. Gallinat (red.): The Ethnographic Self as Resource: Writing Memory and Experience Into Ethnography Oxford: Berghahn, s. 228-245.

Denshire, S. (2014). On auto- ethnography. Current Sociology, 62(6), 831-850. doi: 10.1177/0011392114533339 
Dewey, J. (1980). Art as Experience. New York: Berkeley Publishing Group.

Dreyfus, H. \& Dreyfus, S. (1991). Intuitiv ekspertise: Den bristede drøm om tonkende maskiner. København: Munksgaard.

Dysthe, O. \& Engelsen, K. S. (2011). portfolio practices in higher education in Norway in an international perspective: macro-, meso- and micro-level influences. Assessment \& Evaluation in Higher Education, 36(1), 63-79. doi: 10.1080/02602930903197891

Eisner, E. (2008). Art and knowing. I J. G. Knowles \& A. L. Cole (red.): Handbook of the Arts in Qualitative Research (1st ed.). Thousand Oaks: Sage Publications Inc., 312.

Elmholt, C. (2006). Formidling af kvalitativ metode - eksempel på et undervisningsprogram. Tidsskrift for Kvalitativ Metodeudvikling, (41), 28-31.

Englund, U. (2008). Musik: Metoder til analyse. Århus: Systime.

Giorgi, A. (1975). An application of phenomenological method in psychology. I A. Giorgi (red.): Duqesne Studies in Phenomenological Psychology. vol II. Pittsburg: Duquesne University Press.

Grieg, E. (1876): Morgenstemning. I Grieg, E. (2007). Peer Gynt: Suites nos. 1-2, op. 46 and 55. BBC Scottish Symphony Orchestra; dirigent: Jerzy Maksymiuk. Mainz: Ernst Eulenburg.

Hammersley, M. (2004). Teaching qualitative method: craft, profession, or bricolage? I C. Seale, G. Gobo \& D. Silverman (red.): Qualitative Research Practice (1st ed.). London: Sage, 549-560.

Hastrup, K. (2010). Feltarbejde. I S. Brinkmann \& L. Tanggaard (red.), Kvalitative metoder - en grundbog (1st ed.). København: Hans Reitzels Forlag, 55-80.

Havnes, A., Smith, K., Dysthe, O. \& Ludvigsen, K. (2012). Formative assessment and feedback: making learning visible. Studies in Educational Evaluation, 38(1), 21-27. doi:10.1016/j.stueduc.2012.04.001.

Kristiansen, S. \& Krogstrup, H. K. (1999). Deltagende observation: Introduktion til en samfundsvidenskabelig metode. København: Hans Reitzel.

Langer, S. K. (1969). Menneske og symbol: En studie i fornuftens, ritualets og kunstens symboler. København: Gyldendal.

Lave, J. \& Wenger, E. (2003). Situeret loering - og andre tekster. København: Hans Reitzel.

Polanyi, M. (1958). Personal Knowledge. Towards a Post Critical Philosophy. London: The University of Chicago Press.

Raudaskoski, P. (2010). Observationsmetoder (herunder videoobservation). I S. Brinkmann, \& L. Tanggaard (red.): Kvalitative metoder. En grundbog (1. udg.). København: Hans Reitzels Forlag, 81-96.

Schön, D. A. (2001). Den reflekterende praktiker: Hvordan professionelle toenker når de arbejder. Århus: Klim. 
Statens Samfundsvidenskabelige forskningsråd (2002). Vejledende retningslinjer for forskningsetik i samfundsvidenskaberne. 1st U.S.C. 97.

Tanggaard, L. (2006). Formidling af kvalitativ metode. Tidsskrift for Kvalitativ Metodeudvikling, (41), 3-15.

Vygotsky, L. (1930/2000). Værktøj og symbol i barnets udvikling. I K. Illeris (red.): Tekster om loering (1st ed.). Frederiksberg: Roskilde Universitetsforlag, 83-94.

Wadel, C. (1991). Feltarbeid $i$ egen kultur - en innføring $i$ kvalitativt orientert samfundsforskning. Flekkefjord: SEEK.

Whiting, L. S. (2008). Semi-structured interviews: Guidance for Novice Researchers. Nursing Standard, 22(23), 35-40. 